\title{
Strategi Pengembangan Desa Wisata Berbasis Budaya di Desa Maja, Kecamatan Kalianda, Kabupaten Lampung Selatan
}

\author{
Suwarno*, Abdul Syani, Pairul Syah, Damar Wibisono \\ Sosiologi, Universitas Lampung, Bandar Lampung, 35145, Lampung, Indonesia
}

\begin{abstract}
Abstrak.
Tujuan umum dilakukan kegiatan pengabdian kepada masyarakat ini adalah mensosialisasikan pengembangan desa wisata berbasis budaya di Desa Maja, Kecamatan Kalianda, Lampung Selatan. Kegiatan pengabdian kepada masyarakat ini menggunakan metode ceramah dan diskusi. Metode ceramah dan diskusi di dalam ruangan yang digunakan untuk menyajikan materi. Adapun materi yang akan diberikan adalah peranan kepala pemerintahan adat dalam mewujudkan desa wisata, peranan aparat desa adat dalam mewujudkan desa wisata berbasis budaya,pelayanan publik yang efektif dan efisiendalam mewujudkan desa wisata berbasis budaya, dan penguatan kelembahan dan sinergitas antara pemerintah adat dan aparat desa dalam mewujudkan desa wisata berbasis budaya. Berdasarkan hasil evaluasi dilapangan dapat disimpulkan bahwa setelah peserta mengikuti penyuluhan, pemahaman peserta terhadap materi yang diberikan meningkat sebesar 18,67 \%. Pemahaman peserta sebelum dilakukannya tugas pokok dan fungsi tokoh adat sebesar 60,67, sedangkan setelah dilakukannya penyuluhan menunjukkan adanya meningkatan nilai menjadi 79,33. $\mathrm{Hal}$ ini menunjukkan bahwa pemahaman masyarakat tentang merevitalisasi strategi pengembangan desa wisata berbasis budaya menjadi meningkat. Selain itu, peserta juga terlihat antusiasme peserta mengajukan pertanyaan terkait dengan materi yang diberikan.
\end{abstract}

Kata kunci.

Desa Wisata, Budaya Lokal, Wisata Budaya.

\section{PENDAHULUAN}

Indonesia merupakan sebuah negara yang memiliki berbagai suku bangsa yang masingmasing sukunya memiliki kebudayaan serta adat istiadat yang berbeda-beda. Setiap adat dan budaya memiliki ciri khas sehingga membedakan budaya yang satu dengan yang lain. Keanekaragaman tersebut terjadi karena setiap daerah memiliki kebiasan-kebiasaan yang berbeda sesuai dengan kenekaragaman masyarakatnya. Salah satu adat budaya yang ada di Indonesia adalah adat budaya Lampung.

Sebagai upaya untuk mengembangkan adat budaya Lampung salah satunya yaitu melalui pengembangan desa wisata berbasis budaya. Pariwisata sendiri merupakan

\section{* Corresponding author: suwarno.1965@fisip.unila.ac.id}

Received 18 November 2020; Received in revised form 28 November 2020; Accepted 9 December 2020 Available online 24 December 2020

Lembaga Penelitian dan Pengabdian Kepada Masyarakat

Universitas Lampung 
keseluruhan rangkaian kegiatan yang berhubungan dengan pergerakan manusia yang melakukan perjalanan atau persinggahan sementara dari tempat tinggalnya, ke suatu atau beberapa tempat tujuan di luar lingkungan tempat tinggalnya yang didorong oleh beberapa keperluan tanpa bermaksud mencari nafkah. Pariwisata merupakan salah satu sektor yang sangat penting karena merupakan salah satu sumber devisa Negara dan mampu memberikan sumbangan yang cukup signifikan bagi pembangunan bangsa. Saat ini trend pariwisata mengalami perubahan, dari yang sebelumnya yaitu pariwisata konvensional berubah menjadi pariwisata minat khusus. Pariwisata dapat diartikan suatu aktivitas yang dilakukan oleh wisatawan untuk bepergian ke suatu tempat tujuan wisata di luar keseharian dan lingkungan tempat tinggalnya untuk melakukan persinggahan yang sifatnya sementara waktu dari tempat tinggal, yang didorong beberapa keperluan tanpa untuk bermaksud mencari nafkah, namun didasarkan untuk mendapatkan kesenangan, disertai untuk menikmati berbagai hiburan yang dapat melepaskan lelah dan menghasilkan pengalaman perjalanan berwisata dan pelayanan keramah-tamahan [1].

Pada sektor pariwisata minat khusus wisatawan berkecederungan lebih menghargai lingkungan, alam, budaya dan atraksi secara spesial. Salah satu pariwisata minat khusus yang sedang berkembang di Indonesia adalah desa wisata berbasis budaya. Bentuk kegiatan wisata budaya salah satunya adalah dengan mengunjungi desa wisata. Pemahaman istilah desa wisata cukup beragam. Nuryanti [2] menyebutkan bahwa Desa wisata didefinisikan sebagai bentuk integrasi antara atraksi, akomodasi, dan fasilitas pendukung yang disajikan dalam suatu struktur kehidupan masyarakat yang menyatu dengan tata cara tradisi yang berlaku. Penetepannya harus memenuhi persyaratan di antaranya: 1. Aksesibilitasnya baik, sehingga mudah dikunjungi wisatawan dengan menggunakan berbagai jenis alat transportasi. 2. Memiliki obyek-obyek menarik berupa alam, seni budaya, legenda, makanan lokal, dan sebagainya untuk dikembangkan sebagai obyek wisata. 3. Masyarakat dan aparat desanya menerima dan memberikan dukungan yang tinggi terhadap desa wisata serta para wisatawan yang datang ke desanya. 4. Keamanan di desa tersebut terjamin. 5. Tersedia akomodasi, telekomunikasi, dan tenaga kerja yang memadai. 6. Beriklim sejuk atau dingin. Kaitannya dengan konsep pengembangan desa wisata, Pearce [3] mengartikan pengembangan desa wisata sebagai suatu proses yang menekankan cara untuk mengembangkan atau memajukan desa wisata.

Beberapa daerah di Lampung tidak luput juga mengembangkan jenis pariwisata desa wisata berbasis budaya, salah satunya di daerah Desa Maja Kecamatan Kalianda, Kabuapaten Lampung Selatan. Ada beberapa daya tarik wisata unggulan budaya yang bisa dikembangkan di desa tersebut, baik itu di bidang seni budaya, seni tari, seni musik, kerajinan tangan, pengenalan museum, dan lain sebagainya. Fenomena tersebut menjadi alternatif solusi untuk menjawab trend dunia pariwisata masa kini yang sudah berubah dari wisata konvensional ke wisata minat khusus. Namun, di sisi yang lain timbul berbagai persoalan di antaranya kesiapan berbagai pihak terkait keberadaan desa wisata budaya, kemasan potensi daya tarik desa wisata budaya, permasalahan sarana dan prasarana, permasalahan sumber daya manusia, dan lain-lain. Berdasrkan prariset tanggal 10 Januari 2020 pukul 19.00 WIB, salah satu penyebab belum berkembangnya desa wisata budaya di Desa Maja yaitu karena kurangnya sinergitas antara pemerintan adat dan pemerintahan desa setempat menyebabkan pengembangan desa wisata yang berorientasi budaya belum berjalan maksimal. Selain itu, pembagian tugas yang belum jelas dan belum terlembaga menyebabkan desa wisata yang berbasir budaya di Desa Maja, Kecamatan Kalianda, Kabupaten Lampung Selatan masih berjalan di tempat dan cenderung stagnan.

Dari penjelasan di atas maka perlu dilakukan kegiatan PkM dengan judul "Strategi Pengembangan Desa Wisata Berbasis Budaya di Desa Maja, Kecamatan Kalianda, Kabupaten Lampung Selatan". 


\section{METODE}

\section{Metode Pelaksana}

Kegiatan ini dilaksanakan menggunakan metode Brainstorming, FGD (Focus Group Discution), Case Study, dan Pelatihan

\section{Tahapan Pelaksana}

Pelaksanaan kegiatan ini mulai dari tahapan prapengabdian dengan melakukan studi pendahuluan (Observasi, Dokumentasi, dan Wawancara sederhana) di tempat lokasi pengabdian. Setelah itu, melakukan mapping permasalahan di lapangan melalui Brainstorming dan FGD (Focus Group Discution).

Setelah rangkaian acara Brainstorming dan FGD (Focus Group Discution) dilakukan, kemudian dilakukan sosialisasi tentang strategi pengembangan desa wisata berbasis budaya di Desa Maja, Kecamatan Kalianda, Kabupaten Lampung Selatan

\section{Deskripsi Kegiatan}

Kegiatan Pengabdian ini dilakukan di DesaMaja, Kecamatan Kalianda, Kabupaten Lampung Selatan, Propinsi Lampung. Dalam pelaksanaan seminar akan menggunakan metode ceramah dan diskusi. Metode ceramah dan diskusi di dalam ruangan yang digunakan untuk menyajikan materi. Adapun materi yang akan diberikan adalah peranan kepala pemerintahan adat dalam mewujudkan desa wisata, peranan aparat desa adat dalam mewujudkan desa wisata berbasis budaya, pelayanan publik yang efektif dan efisiendalam mewujudkan desa wisata berbasis budaya, dan penguatan kelembahan dan sinergitas antara pemerintah adat dan aparat desa dalam mewujudkan desa wisata berbasis budaya.

Kegiatan penyuluhan tentang strategi pengembangan desa wisata berbasis budaya di Desa Maja, Kecamatan Kalianda, Kabupaten Lampung Selatan secara umum diharapkan dapat dijadikan penguat dan pendukung kegiatan pengabdian sebelumnya tentang peranan tokoh adat dalam pengembangan desa wisata.

\section{Prosedur Kerja}

Tim melaksanakan pendampingan di lapangan sesuai dengan kegiatan yang telah direncanakan. Selain itu, tim akan melakukan kontrol pada setiap tahapan yang akan dilakukan, serta melakukan evaluasi disetiap kegiatan pada tahap akhir implementasi kegiatan.

\section{Pihak-pihakyang terlibat}

Kegiatan melibatkan beberapa komponen masyarakat, yaitu akademisi (mahasiswa dan Dosen), pemerintah desa, masyarakat yang ada di daerah Pengabdian, serta pihak-pihak yang memerlukan kegiatan ini sebagai pengetahuan ke depan seperti pemerintah adat, aparat desa, masyarakat setempat, dan lain sebagainya.

\section{Keterlibatan Mitra}

Mitra yang terlibat dalam kegiatan ini adalah para pemimpin formal yang ada di desa Desa Maja, Kecamatan Kalianda, Lampung Selata dan para pimpinan informal yaitu tokoh adat, tokoh masyarakat, pemuka agama, LSM, guru, dan lain-lain.

\section{Evaluasi Pelaksana dan Keberlanjutan}

Evaluasi dalam kegiatan penyuluhan ini dibedakan menjadi dua macam, yaitu: 
a. Evaluasi Perubahan Pengetahuan

Evaluasi ini dilakukan dengan pre-test dan post-test. Selisih antara post-test dan pretest dinyatakan dalam persen. Pertambahan tersebut kemudian dikelompokan dalam strata buruk, sedang dan baik.

b. Evaluasi Dampak

Evaluasi ini dilakukan sebelum kegiatan seminar berakhir Mekanismenya dengan membagikan kuesioner kepada sasaran dan dihitung berapa orang peserta yang telah menguasai materi dengan baik dalam pelaksanaan tugasnya.

\section{HASIL DAN PEMBAHASAN}

\section{Realisasi Kegiatan}

Adapun realisasi kegiatan Pengabdiaan kepada Masyarakat dengan tema "Strategi Pengembangan Desa Wisata Berbasis Budaya di Desa Maja, Kecamatan Kalianda, Kabupaten Lampung Selatan" bersama peserta terkait tema tersebut. Kemudian tim memberikan materi dengan alur kegiatan sebagai berikut:

Tabel 1. Realisasi Kegiatan.

\begin{tabular}{|c|c|c|}
\hline \multirow{5}{*}{1 . } & Nama Materi & $\begin{array}{l}\text { Latar Belakang Pengembangan Desa Wisata } \\
\text { Berbasis Budaya }\end{array}$ \\
\hline & Pertemuan ke - & $: 1$ \\
\hline & Waktu Penyampaian & : 1,5 jam \\
\hline & Metode Penyampaian & : Ceramah, Diskusi, Simulasi \\
\hline & Sarana & : LCD dan Peralatan Simulasi \\
\hline \multirow{5}{*}{2.} & Nama Materi & $\begin{array}{l}\text { Konsep, Tujuan, dan Faktor-faktor Pendukung } \\
\text { Kemajuan Desa Wisata Berbasis Budaya }\end{array}$ \\
\hline & Pertemuan ke - & $: 2$ \\
\hline & Waktu Penyampaian & $: 1,5 \mathrm{jam}$ \\
\hline & Metode Penyampaian & : Ceramah, Diskusi, Simulasi \\
\hline & Sarana & : LCD dan Peralatan Simulasi \\
\hline \multirow{5}{*}{3.} & Nama Materi & $\begin{array}{l}\text { Strategi Pengembangan Desa Wisata Berbasis } \\
\text { Budaya }\end{array}$ \\
\hline & Pertemuan ke - & $: 3$ \\
\hline & Waktu Penyampaian & : 1,5 jam \\
\hline & Metode Penyampaian & : Ceramah, Diskusi, Simulasi \\
\hline & Sarana & : LCD dan Peralatan Simulasi \\
\hline \multirow{6}{*}{4.} & Nama Materi & : Pengenalan Benda-benda Budaya untuk \\
\hline & Naina ividen & Pengembangan Desa Wisata Berbasis Budaya \\
\hline & Pertemuan ke - & $: 4$ \\
\hline & Waktu Penyampaian & $: 1,5$ jam \\
\hline & Metode Penyampaian & : Ceramah, Diskusi, Simulasi \\
\hline & Sarana & : LCD dan Peralatan Simulasi \\
\hline
\end{tabular}

\section{Hasil dan Evaluasi}

Evaluasi dalam kegiatan ini dilakukan dengan cara: 
1. Penjajagan pengetahuan dan pemahaman peserta melalui soal Pre-Test dan diskusi dengan menggunakan evaluasi awal. Cara ini digunakan untuk mengetahui tingkat pengetahuan dan pemahaman peserta.

2. Memberikan materi dan peserta diberikan materi yang berkaitan dengan latar belakang pengembangan desa wisata berbasis budaya, konsep, tujuan, dan faktorfaktor pendukung kemajuan desa wisata berbasis budaya, strategi pengembangan desa wisata berbasis budaya, dan pengenalan benda-benda budaya untuk pengembangan desa wisata berbasis budaya.

3. Evaluasi akhir (Post-Test) dan diskusi atas masalah-masalah yang belum dipahami berkaitan dengan materi yang disampaikan.

Pada kegiatan ini dilakukan evaluasi sebanyak dua kali yaitu evaluasi awal (Pre-Test) dan evaluasi akhir (Post-Test). Evaluasi awal dilaksanakan sebelum peserta mendapat materi, sebagai upaya untuk mengetahui tingkat pengetahuan para peserta sebelum penyuluhan. Evaluasi awal dilakukan dengan memberikan soal-soal singkat sesuai dengan materi yang akan diberikan.

Evaluasi akhir dilaksanakan pada akhir kegiatan, setelah para peserta mengikuti semua materi yang diberikan. Evaluasi akhir dilakukan dengan memberikan soal-soal yang berkaitan dengan materi yang disajikan, sebagai upaya untuk mengetahui perkembangan/peningkatan pemahaman serta pengetahuan para peserta tentang materi yang diberikan. Adapun evaluasi hasil pre-test dan post-test dapat dilihat dalam tabel berikut:

Tabel 2. Hasil Evaluasi Kegiatan.

\begin{tabular}{cccc}
\hline No Peserta & Nilai Pre-test & Nilai Post-test & Persentase Kenaikan \\
\hline 1 & 60 & 70 & 30 \\
2 & 50 & 80 & 30 \\
3 & 70 & 80 & 20 \\
4 & 60 & 90 & 30 \\
5 & 60 & 80 & 20 \\
6 & 60 & 80 & 30 \\
7 & 60 & 70 & 10 \\
8 & 70 & 80 & 10 \\
9 & 60 & 90 & 20 \\
10 & 60 & 70 & 20 \\
11 & 60 & 80 & 20 \\
12 & 60 & 80 & 10 \\
13 & 60 & 80 & 20 \\
14 & 60 & 80 & 20 \\
15 & 60 & 80 & 0 \\
\hline Rata-rata & 60.67 & 79.33 & 18.67 \\
\hline
\end{tabular}

\section{Pembahasan}

Berdasarkan tabel 3 di atas, dapat dilihat adanya peningkatan rata-rata pemahaman peserta terhadap materi yang diberikan sebesar $18,67 \%$. Berdasarkan tabel tersebut juga dapat dilihat bahwa pemahaman peserta sebelum dilakukannya kegiatan "Strategi Pengembangan Desa Wisata Berbasis Budaya di Desa Maja, Kecamatan Kalianda, Kabupaten Lampung Selatan" yang menyangkut materi latar belakang pengembangan desa wisata berbasis budaya, konsep, tujuan, dan faktor-faktor pendukung kemajuan desa wisata berbasis budaya, strategi pengembangan desa wisata berbasis budaya, dan pengenalan benda-benda budaya untuk pengembangan desa wisata berbasis budaya relatif rendah yaitu sekitar 60,67, sedangkan setelah dilakukannya sosialisasi menunjukkan adanya peningkatan nilai menjadi 79,33. Fakta menarik lainnya berdasarkan tebel 3 yaitu adanya peningkatan pemahaman beberapa peserta hingga 18,67\%. Hal ini menunjukkan bahwa peserta yang sangat antusias dalam mengikuti kegiatan ini dan mampu menangkap secara baik materi yang diberikan selama kegiatan.

Selain data tersebut di atas, antusias peserta ditunjukkan juga melalui partisipasi aktif peserta yang mampu merespon pertanyaan termasuk dari segi substansi jawaban peserta 
terhadap pertanyaan pada saat diskusi, serta kemampuan peserta dalam melakukan simulasi yang diberikan.

Dengan demikian, dapat disimpulkan bahwa kegiatan ini memberikan peningkatan pemahaman para peserta tentang Strategi Pengembangan Desa Wisata Berbasis Budaya di Desa Maja, Kecamatan Kalianda, Kabupaten Lampung Selatan.

\section{KESIMPULAN DAN SARAN}

\section{Kesimpulan}

Berdasarkan hasil evaluasi awal (pre-test) dan dan evaluasi akhir (post-test) dari kegiatan penyuluhan yang dilakukan, maka dapat ditarik kesimpulan sebagai berikut:

a. Kegiatan pengabdian dengan tema "Strategi Pengembangan Desa Wisata Berbasis Budaya di Desa Maja, Kecamatan Kalianda, Kabupaten Lampung Selatan" mampu memberikan pengetahuan terhadap peserta. Hal ini dapat dilihat adanya peningkatan pemahaman peserta sebesar $18,67 \%$. Selain itu, partisipasi aktif peserta yang mampu merespon setiap pertanyaan yang diberikan pemateri mengindikasikan pemahaman peserta menjadi meningkat.

b. Meningkatnya pemahaman masyarakat tentang latar belakang pengembangan desa wisata berbasis budaya, konsep, tujuan, dan faktor-faktor pendukung kemajuan desa wisata berbasis budaya, strategi pengembangan desa wisata berbasis budaya, dan pengenalan benda-benda budaya untuk pengembangan desa wisata berbasis budaya. Hal ini dapat terlihat dari tingkat antusiasme peserta dalam mengajukan pertanyaan terkait dengan materi yang diberikan.

c. Tumbuhnya pengetahuan para peserta. Hal ini dapat dilihat dari hasil evaluasi yang menunjukkan adanya peningkatan pemahaman sebesar $18,67 \%$ serta antusiasme peserta dalam mengikuti kegiatan secara keseluruhan.

\section{Saran}

Berdasarkan kesimpulan di atas, penulis mengajukan saran antara lain:

1. Kegiatan penyuluhan dan sosialisasi serupa seyogyanya perlu dilakukan secara terus menerus. Karena terbukti mampu meningkatkan pengetahuan para peserta tertutama terkait dengan bagaimana pentingnya peran serta masyarakat terutama dalam hal pengembangan desa wisata berbasis budaya.

2. Kegiatan serupa perlu dilaksanakan recara rutin untuk menjaga dan melestarikan nilai kearifan lokal dalam rangka pengembangan desa wisata berbasis budaya di Desa Maja, Kecamatan Kalianda, Kabupaten Lampung Selatan.

\section{DAFTAR PUSTAKA}

[1] Inskeep, E. 1991. Tourism Planning, and Integrated and Sustainable Development Approach. New York: Van Nostrand Reinhold.

[2] Nuryanti, W. 1999. Heritage, Tourism and Local Communities. Yogyakarta: UGM Press.

[3] Pearce, D. 1995. Tourism a Community Approach. 2nd: Harlow Longman. 